\title{
Entrepreneurship Education and Previous Work Experience on Business Creation in Nigeria
}

\author{
Ayodeji Muyideen Awolaja \\ Ekiti State University, \\ Department of Business Administration \\ Omobola Monsurat Ajayi, (PhD) \\ Ekiti State University, \\ Department of Business Administration
}

\begin{abstract}
The study examined the effects of entrepreneurship and previous work experience on business creation in Nigeria among students of Ekiti State University. The research adopted a descriptive of survey research. The total population for the study was 9250 gotten from the various registries in all the faculties of the university. The sample size for the research was 400 through the Taro and Yamane (1992) model. Result of the regression estimation revealed that coefficient estimates of 0.287 and 0.631 with the probability values of 0.493 and 0.142 for entrepreneurship education and prior work experience exert a positive impact on business creation among undergraduate students of Ekiti State University. The result reflects that increase in the level of entrepreneurship education and prior work experience will trigger a corresponding increase in the level of business creation among students of Ekiti state university to the tune of $0.287,0.631$ in terms of business creation score. Based on the discoveries and the analysis conducted in the study, it can be concluded that entrepreneurship education with prior work experience only contributes mildly to business creation among undergraduate student in Ekiti state. Prior exposure to the world of business encourages undergraduate students to create a business of their own.
\end{abstract}

\section{INTRODUCTION}

Entrepreneurship education has become a serious matter for university administrators, course developers, government (public) servants, and researchers Kuratko (2005). One reason for the increasing interest in entrepreneurship education is the impact of entrepreneurship on business creation and creation of employment opportunities (Audretsch, Grilo, \&Thurik, 2011), even though the prevalence rate of entrepreneurship is low; for example, in high-income countries, less than $10 \%$ of the adult population is involved in entrepreneurial activities (Xavier ,Kelley, Herrington \&Vorderwulbecke 2012). By promoting entrepreneurship education, students can further generate finance and wealth. Entrepreneurship education could be one way to increase the passion of students to own a business and thereby, reduce poverty rate of youths in the economy.

Since entrepreneurship was introduced by the united state in the 1940s, this concept has been adopted and integrated into education in many countries (Nigeria being one of them) as a component of new economic strategies for fostering job creation. It has become such an important part of education that in 1998, UNESCO World Conference recognized its value and advocated cultivating entrepreneurship and skills in higher education. In the late 1990s, following the international trend, Nigeria began witnessing entrepreneurship education emerge on individual campuses in university students entrepreneurship competitions. 
Challenged by the growing enrollments and the difficulty of undergraduate employment, Minister of Education, Mallam Ibrahim Shekarau while declaring open the 2014 Annual National Entrepreneurship Week (ANEW), and stakeholders' sensation forum, organized by National Universities Commission (NUC), and Kaduna State University in Abuja, Nigeria stated that the Federal Government revealed that it had made the study of entrepreneurship compulsory in universities and other institutions of learning. According to him, this will discourage Nigerian graduates from craving for non-existent white-collar jobs. He said this would deal with the vexed issues of the low employability rating of Nigerian graduates and the general unemployment problems confronting the nation. "Against this backdrop, the Federal Government in 2006 issued a Presidential directive through the Federal Ministry of Education making Entrepreneurship Education compulsory for all students of Higher Education Institutions with effect from the 2007/2008 academic session. Entrepreneurial behavior research has used intention models to explain how an individual's beliefs shape the attitudes and motivations that influence business creation. With experience behind you, you're ready to start your own entrepreneurial project. You plan and strategize forever, but at a certain point you've got to bite the bullet and see if your idea works in the real world (Fiet,2002).

Prior research explores the influence of entrepreneurial knowledge to study the drivers of experienced individuals evaluating whether or not to engage in an entrepreneurial behavior (Riverola, \&Giones, 2016). Despite the extant prior research on entrepreneurial behavior, little is known on the entrepreneurial behavior drivers for individuals of working age with experience.

Business creation through entrepreneurship education offers university graduates and undergraduates the opportunity to create jobs for themselves and others. According to Beeka and Rimmington (2011) and Buang (2011), entrepreneurship is one of the career options for youths and graduates. Entrepreneurship education and business creation is one of the options to reduce the unemployment rate and the social problems that are associated with unemployment. There is diversity of views among academics about what constitutes "entrepreneurship" as a field of study as well as what constitutes an entrepreneurship program. In the United States, entrepreneurship generally refers to growth-oriented ventures or companies, and an entrepreneurship program promotes skills for building, financing, and nurturing high-growth companies. The primary purpose of entrepreneurship education in Ekiti State University (EKSU), Ado-Ekiti is to develop entrepreneurial capacities and mindsets that supports undergraduates and graduates in day-to-day life at home and in society and provide a foundation for entrepreneurs establishing a social or commercial activity. The faculty of Management Sciences at EKSU is one of the greatest faculties in the university. This faculty offers series of courses relating to entrepreneurship which focus on the study and the cultivation of entrepreneurial management knowledge and skills.

Entrepreneurship Education has become more complex and plays a big part in eradicating unemployment among youths thereby fostering business creation. It has been argued that an important driving force behind entrepreneurship education and previous work experience is independent work which may help create business and can be a valuable opportunity for academic youths to bring the skills gained in educational institutions to practice as well as the job they like most.

However, There exists a dearth in the empirical review relating to the study under investigation, Pardo (2013) wrote on Is Business Creation the mean or the End of Entrepreneurship Education? ; Riverola and Giones (2016) Evaluating the Impact of Previous 
Work Experience in Entrepreneurial Intentions; and Fatoki (2014) the Influence of Entrepreneurship Education and Previous Work Experience. In this study we would consider the students intentions, behaviors and plans towards business creation based on the schools' entrepreneurship education system.

\section{Concept of Entrepreneurship Education}

\section{LITERATURE REVIEW}

Entrepreneurship education is not just about teaching someone to run a business. It is about encouraging creative thinking and promoting a strong sense of self-work and accountability. Through entrepreneurship education, students learn how to create a business and lots more. In this same vein Jimah and Unuigbokhai (2011) sees entrepreneurship education as seeking to prepare people, especially youths, to be responsible, enterprising individuals who become entrepreneurs or entrepreneurial thinkers and who contribute to economic development and sustainable communities.

\section{Previous Work experience}

According to Shane(2000), Parker and Praag (2012), there are several ways to become an entrepreneur; two distinct methods are (1) either starting a new business venture or (2) taking over an existing business because of your previous work experience. Work experience is any experience that a person gains while working in a specific field or occupation, but the expression is widely used to mean a familiarity with a skill or field of knowledge acquired over months or years of actual practice and which presumably, has resulted in superior understanding or mastery.

\section{Business Creation}

According to Riverola and Giones(2016) business creation leads to job creation in that after learning about business creation you then create job opportunities for job seekers. Business creation is important to the wellbeing of an economy and has become an urgent national priority following the recent financial crisis and trend of unemployment among undergraduates.

Faley (2005) opined that creating a new business is a process that goes well beyond the insightful flash that hits you during your morning shower.

\section{Theoretical Framework}

This project is anchored on Opportunity-Based Entrepreneurship theory by (Fiet, 2002 and Shane, 2000) because it is the most related and relevant theory to this project.

An opportunity-based entrepreneurship theory provides a wide-ranging conceptual framework for entrepreneurship research. Entrepreneurs do not cause change (as claimed by Schumpeterian or Austrian school) but exploit the opportunities that change (in technology, customer preference e.t.c) creates. They explained further that good entrepreneurs always search for change, responds to it and exploits it as an opportunity to start-up more business. What is apparent in this theory is that entrepreneurs have an eye for more possibilities created by change than the problem (Fiet, 2002 and Shane, 2000). Though the entrepreneurial process begins with opportunities, it entails other important elements. Such elements include assembling resources, managing a growing concern, growing a business venture, and others.

\section{METHODS}

The research study will adopt the descriptive of survey research. It will be descriptive research because it will be planned collection of data from a large population, which will be meant to 
describe the characteristics of the research variables and phenomenon about the population of the study. Data and information will be collected to describe relationships between the three variables. This fits into the picture of the study as researcher investigates the impact of Entrepreneurship Education, Previous Work Experience and Business Creation with reference to students of Ekiti State University. The total population for the study was 9250 gotten from the various registry in all the faculties of the university

\section{Sample Size and Sampling Technique}

According to Adetayo (2011), sampling is the process of selecting a sufficient number of elements from the population, so that by studying the sample, and understanding the properties of the characteristics of the sample subject, the researcher will be able to generate the characteristics of the population elements. The researcher shall draw sample of this study from the total population of students in the faculties of management sciences and social science through the adoption of Taro and Yamane (1992) model to decide the sample of the study. Also random sampling and stratified sampling techniques will be used to select the sample that shares the same characteristicsin order to make sure that every member of these faculties is represented.Stratified sampling techniques were used to divide the students into strata so that the number of respondents chosen for each strata will represent the faculties.

The Taro and Yamane (1992) model is given as:

$$
\mathrm{n}=\frac{\mathrm{N}}{1+\mathrm{N}(\mathrm{e})^{2}}
$$

Where $\mathrm{n}=$ anticipated total sample size

$\mathrm{N}=$ population size

$\mathrm{E}=$ degree or level of significance (5\% i.e. 0.05$)$

Therefore, the total sample shall be computed as:

$$
\begin{aligned}
& \mathrm{n}=\frac{9150}{1+9150(0.05)^{2}} \\
& \mathrm{n}=399.984 \\
& \text { Approx. to } 400 \text { respondents }
\end{aligned}
$$

For effective coverage, stratified sampling technique was used to select the participating respondents. The population was grouped into five strata (Management Sciences, Agricultural Sciences, Engineering, Sciences and Social Sciences) based on the population of each faculty. Karan (1967) model was used to calculate the sample size of each stratum

\section{Method of Data Collection}

Questionnaire shall be the main source of data collection. The response shall be required on Five-point Likert Scales \{endpoints: 1 = strongly disagree (SD); 2 = disagree (D); 3 = Undecided (U); 4 = Agree (S), and 5 = strongly agree (SA).

\section{Method of Data Analysis}

The data gathered shall be sorted, coded, and analyzed using descriptive and inferential statistics. The descriptive statistics shall be mainly frequency table while inferential statistics shall be regression analysis. Simple regression analysis shall be adopted to examine the impact 
of entrepreneurship education and previous work experience on business creation among undergraduate students of Ekiti State University with due consideration to each research objective.

\section{Demographic Details of the Respondents}

\section{RESULTS}

This section presents descriptive analysis of the demographic details of respondents covered in the study. Details of the respondents presented include: Sex of respondent, Age of respondents, Sex of respondents, age of respondents, level of respondents as well as faculty of the respondents.

Table 1.1 Distribution of Respondents by Gender

\begin{tabular}{|c|c|c|c|}
\hline Variable & Detail & Frequency & Percentage \\
\hline Gender & Male & 192 & 48.0 \\
\hline & Female & 208 & 52.0 \\
\hline & Total & 400 & 100.0 \\
\hline
\end{tabular}

Source: Field Survey (2019)

Table 1.1 presents the distribution of respondents by Sex. Notable, the table reveals that $192(48.0 \%)$ of the total respondent are male, while $208(52.0 \%)$ of the total respondents are female. This result conspicuously connotes that there are more of female respondents than male though there is no evidence of gender biasness.

Table 1.2 Distributions of Respondents by Age

\begin{tabular}{|c|c|c|c|}
\hline Variable & Detail & Frequency & Percentage \\
\hline Age & $13-19$ & 62 & 15.5 \\
\hline & $20-26$ & 277 & 69.3 \\
\hline & $27-33$ & 61 & 15.3 \\
\hline & Total & $\mathbf{4 0 0}$ & $\mathbf{1 0 0 . 0}$ \\
\hline
\end{tabular}

Source: Field Survey (2019)

Table 1.2 presents the distribution of respondents by age. Notable, the table showed that 62 $(15.5 \%)$ of the respondents fall between the age of 13 and 19 years, $277(69.3 \%)$ of the respondents falls between the age of 20 and 26, 61 (15.3\%) of the respondents falls between the age 27 and 33 years. Hence, it is obvious that majority of the students sampled falls under the age bracket of 20-26 years.

Table 1.3 Distributions of Respondents by Level

\begin{tabular}{|c|c|c|c|}
\hline Variable & Detail & Frequency & Percentage \\
\hline Level & 100 LEVEL & 60 & 15.0 \\
\hline & 200 LEVEL & 50 & 12.5 \\
\hline & 300 LEVEL & 103 & 25.8 \\
\hline & 400 LEVEL & 120 & 30.0 \\
\hline & 500 LEVEL & 67 & 16.8 \\
\hline & Total & $\mathbf{4 0 0}$ & $\mathbf{1 0 0 . 0}$ \\
\hline
\end{tabular}

Source: Field Survey (2019)

Table 1.3 presents the distribution of respondents by level. Notable the table showed that 60 $(15.0 \%)$ of the total respondents are 100 level students, 50 (12.5\%) of the respondents are 200 level students, $103(25.8 \%)$ of the respondents are 300 level students, $120(30.0 \%)$ of the respondents are 400 level students while $67(16.8 \%)$ of the total respondents are 500 level students. 
Table 1.4 Distribution of Respondents by Faculty

\begin{tabular}{|c|c|c|c|}
\hline Variable & Detail & Frequency & Percentage \\
\hline Level & SOCIAL SCIENCE & 92 & 23.0 \\
\hline & SCIENCE & 76 & 19.0 \\
\hline & $\begin{array}{c}\text { AGRICULTURAL } \\
\text { SCIENCE }\end{array}$ & 68 & 17.0 \\
\hline & $\begin{array}{c}\text { MANAGEMENT } \\
\text { SCIENCES }\end{array}$ & 108 & 27.0 \\
\hline & ENGINEERING & 56 & 14.0 \\
\hline & Total & $\mathbf{4 0 0}$ & $\mathbf{1 0 0 . 0}$ \\
\hline
\end{tabular}

Source: Field Survey (2019)

Table 1.4 presents the distribution of respondents by faculty. Notable, the table shows that 92 $(23 \%)$ of the total respondents are students from the faculty of social sciences, $76(19 \%)$ of the respondents are students from the faculty of sciences, $68(17 \%)$ of the respondents are students from the faculty of agricultural science, $108((27 \%)$ of the respondents are students from the faculty of management sciences, while $56(14 \%)$ of the total respondents are students from the faculty of engineering.

\section{Correlation Analysis}

Table 1.5: Correlation Matrix

\begin{tabular}{|c|c|c|c|}
\hline & BC & EE & PWE \\
\hline BC & 1 & & \\
\hline EE & $0.762^{* *}$ & 1 & \\
\hline PWE & $0.788^{* *}$ & $0.913^{* *}$ & 1 \\
\hline
\end{tabular}

Source: Author's Computation, (2019)

Table 1.5 presents correlation coefficient for pairs of variables used in the study. Specifically the table reported correlation statistics of $0.762,0.788$, and 0.913 for BC and EE, BC and PWE, EE and PWE respectively. The result revealed that there is positive relationship between pairs of variables used in the study. Notably the result showed thatbusiness creation increases over time alongside increase in entrepreneurship education as well as prior work experience.

\section{Regression Analysis}

Table 1.6: Regression Estimation Result

Dependent Variable: Business Creation

\begin{tabular}{|c|c|c|c|c|}
\hline Variable & Coefficient & Std Error & t-statistics & Prob. \\
\hline C & 6.571 & 16.856 & 0.390 & 0.702 \\
\hline EE & 0.287 & 0.409 & 0.701 & 0.493 \\
\hline PWE & 0.631 & 0.409 & 1.541 & 0.142 \\
\hline
\end{tabular}

R-Squared $=0.632$

Adjusted R-Square $=0.589$

F-statistics $=14.590$

Prob(F-statistics) $=0.000$

Result of the regression estimation presented in table 1.6 revealed coefficient estimates of 0.287 and 0.631 with the probability values of 0.493 and 0.142 for entrepreneurship education and prior work experience The result revealed that both entrepreneurship education and prior work experience exert positive impact on business creation among undergraduate students of 
Ekiti State University. The result reflect thatincrease in the level of entrepreneurship education and prior work experience will trigger a corresponding increase in the level of business creation among students of Ekiti state university to the tune of $0.287,0.631$ in terms of business creation score.However probability values presented in table 4.6 showed that impact of both entrepreneurship education and prior work experience on business creation is not statistically significant in the context of undergraduate students sampled in the study. R-square statistics reported in table 1.6 stood at 0.632 , which implies that about $63 \%$ of the systematic variation in business creation can be explained by joint variation in entrepreneurship education and prior work experience. F-statistics and probability values reported in the table reflect that the model is a good fit, with the probability value of the reported statistics less than 0.05

\section{DISCUSSION OF FINDINGS}

From the empirical investigation conducted in the study with focus on analyzing the impact of entrepreneurship education on business creation among Ekiti State University undergraduatestudents, the following discoveries were made: Firstly, the study discovered that entrepreneurship education exert insignificant positive impact on business creation among undergraduate students of Ekiti State University.The result reflect that the more undergraduate students are subjected to entrepreneurship education the higher the likelihood of business creation, however the fact that the observed positive impact of entrepreneurship education on business creation in the context of undergraduate students of Ekiti state University tends not to be significant reflect that there is still a long ground to cover in the discourse of entrepreneurship education of undergraduate student in Ekiti state. the result fundamentally stress that while entrepreneurship education in Ekiti State University has the capacity to spur the level of business creation among undergraduate student, other factors of reality might need to be put into consideration, so that the effect of entrepreneurship education on business creation might become pronounced. It is also important to stress thatentrepreneurship education is highly dependent on acceptance of entrepreneurial mindset of undergraduate students and the creation of entrepreneurial environment in and around the university. in a nutshell since entrepreneurial education is technically designed to communicate and inculcate competencies, skills and values needed to recognize business opportunities, organize and start new business ventures, it importance in the discourse of business creation cannot be overemphasized. secondly the study discovered that prior work experience exert positive but insignificant impact on business creation among undergraduate students in Ekiti State University, which by implication reflect thatpriori exposure to the world of business encourages undergraduate student to want to create their own business however the observed impact of priori work experience is not pronounce in the context of undergraduate students sampled in the study. this among other things might be attributed to the work load of school, depicted by time spent in lecture as well as the stress exposed to in then learning environment, which student have to incorporate into their quest to create business engagement, since their education will be too important to trade off just for business creation.

\section{CONCLUSION AND RECOMMENDATIONS}

Based on the discoveries and the analysis conducted in the study, it can be concluded that entrepreneurship education with prior work experience only contribute mildly to business creation among undergraduate student in Ekiti state. Prior exposure to the world of business encourages undergraduate students to create a business of their own. 


\section{Recommendations}

Based on the findings, result and conclusions, the study thus recommended that entrepreneurship educators in Ekiti State University should point attention of undergraduate student to other salient factors that might significantly influence their engagement in business endeavor and logically presents possible ways of working around identified short comings. School authorities should incorporate educative programs and vocational training that will widen the knowledge of students in the area of business so as to be able to stand out among their competitors in the business environment. School management should also provide aids in terms of technical and financial assistant to undergraduate students willing to engage in productive business activities.

\section{Reference}

Adetayo, D. (2011).Guide to business research and thesis writing. Ibadan, Nigeria: Rasmed PublicationsLimited.

Audretsch, D. B., Grilo, I., \&Thurik, A. R. (2011). Globalization, entrepreneurship, and the region. In M. Fritsch (Ed.), Handbook of research on entrepreneurship, 11-32. Cheltenham: Edward Elgar.

Beeka, B. H., \&Rimmington, M. (2011). Entrepreneurship as a career option for African youths. Journal of Development Entrepreneurship, 16(1), 145-164.

Faley, T. (2005). The process of business creation. Retrieved from https://www.inc.com/resources/startup/articles/20050801/process.html

Fatoki, 0. (2014). The entrepreneurial intention of undergraduate students in South Africa: The influence of entrepreneurship education and previous work experience.Mediterranean Journal of Social Sciences, 5(7), 294299.

Fiet, J.O. (2002). The pedagogical side of teaching entrepreneurship.Journal of Business Venturing, 16(1), 1-24.

Jimah, M.S.,\&Unuigbokhai, O.A.(2011).Entrepreneurship education: A tool for sustainable development in Nigeria. Retrieved from https://msjlib.wordpress.com/2011/09/10/entrepreneurship-education/

Kuratko, D. F. (2005). The emergence of entrepreneurship education: Development, trends, and challenges. Entrepreneurship, Theory and Practice, 29, 577-597

Pardo, C. A. (2013). Is Business Creation the Mean or the End of Entrepreneurship Education? AMultiple Case Study Exploring Teaching Goals in Entrepreneurship Education. Journal of Management, Technology and Innovation, 8(1), 1-9.

Parker, S.C., \&Praag, C.M. (2012). The entrepreneur's mode of entry: Business takeover or new venture start? Journal of Business Venturing, 27(1), 31-46.

Riverola, C., \&Giones, F. (2016). Evaluating the impact of prior experience in entrepreneurial intention in Denmark. International Entrepreneurship and Management Journal, 12(3), 791-813.

Shane, S. (2000). Prior knowledge and the discovery of entrepreneurial opportunities. Organization Science, 11(4), 448-469.

Xavier, S.R., Kelley, D., Herrington, M., \&Vorderwulbecke, A. (2012). Global entrepreneurship monitor.Cape Town, Global Report.

Yamane, T. (1967). Statistics: An introductory analysis. New York: Harper and Row. 